\title{
Antibiotic Utilization in Halal Animal Production: Shariah Perspective
}

Nurulaina Saidin, Zulaipa Ruzulan, Mohd Ashrof Zaki Yaakob and Fadilah Abd. Rahman

To Link this Article: http://dx.doi.org/10.6007/IJARBSS/v11-i11/11177

DOI:10.6007/IJARBSS/v11-i11/11177

Received: 09 September 2021, Revised: 11 October 2021, Accepted: 27 October 2021

Published Online: 10 November 2021

In-Text Citation: (Saidin et al., 2021)

To Cite this Article: Saidin, N., Ruzulan, Z., Yaakob, M. A. Z., \& Rahman, F. A. (2021). Antibiotic Utilization in Halal Animal Production: Shariah Perspective. International Journal of Academic Research in Business and Social Sciences, 11(11), $755-763$.

\section{Copyright: (c) 2021 The Author(s)}

Published by Human Resource Management Academic Research Society (www.hrmars.com)

This article is published under the Creative Commons Attribution (CC BY 4.0) license. Anyone may reproduce, distribute, translate and create derivative works of this article (for both commercial and non-commercial purposes), subject to full attribution to the original publication and authors. The full terms of this license may be seen at: http://creativecommons.org/licences/by/4.0/legalcode

Vol. 11, No. 11, 2021, Pg. $755-763$

Full Terms \& Conditions of access and use can be found at http://hrmars.com/index.php/pages/detail/publication-ethics 


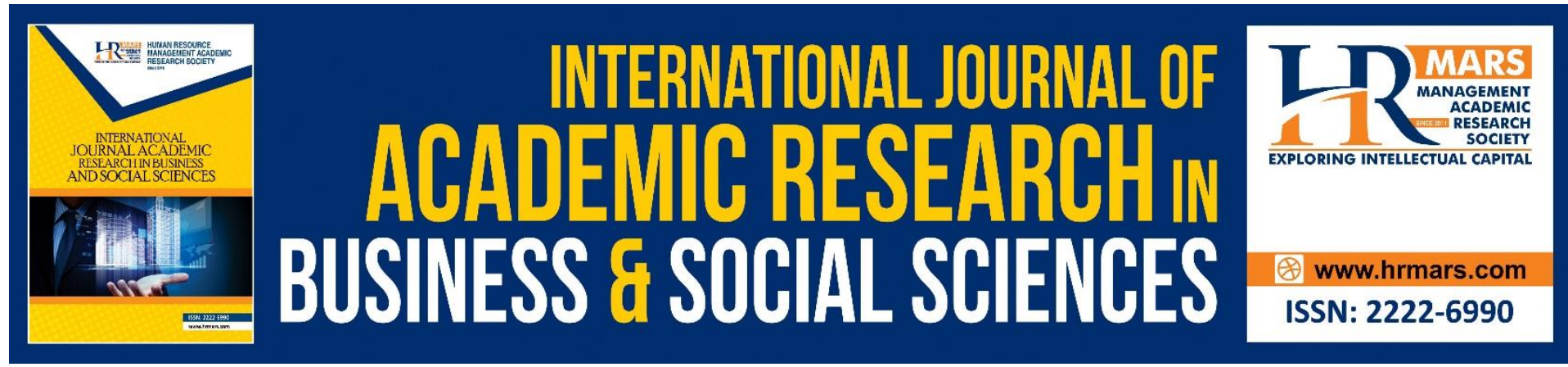

\title{
Antibiotic Utilization in Halal Animal Production: Shariah Perspective
}

\section{Nurulaina Saidin, Zulaipa Ruzulan, Mohd Ashrof Zaki Yaakob and Fadilah Abd. Rahman}

Academy of Contemporary Islamic Studies, Universiti Teknologi Mara, Malaysia Corresponding Author: nurulainasaidin@uitm.edu.my

\begin{abstract}
Antibiotic has long been used in animal production to treat disease, preventing and controlling common disease occurrence, and enhance animal growth rate. Despite the positive impact of antibiotics on animal production through the years, uncontrolled utilization of this compound demonstrates an increase in the occurrence of resistant bacteria known as 'superbug' which eventually can cause serious illness if passed to humans. Amongst the criteria for feed utilized for halal animal production include free from prohibited antibiotics and other chemicals, besides also be free from porcine and filthy sources, synthetic hormones, and contain a safe level of biological, chemical, and physical contaminants. This article seeks to identify and analyze issues related to antibiotic utilization and the Islamic position on its utilization in halal animal production specifically in feed and feeding practices. Complete understanding of the current issues pertaining to antibiotics utilization in Malaysia and Shariah perspective on this issue could increase awareness among Malaysian, especially Muslim on the best practices for animal feeding and farming. The study utilizes a qualitative approach using library research, in which data from relevant literatures and research had been collected and analysed. The findings of the study demonstrated that there are significant research and reports of antibiotic resistance bacteria detected in food and animals in Malaysia. Besides, it is found that from the Islamic perspective, excessive utilization of antibiotics in animal production, especially as a growth promoter, is indeed not according to the principle of Maqasid al-Shariah which aims to protects human life and lineage and reject any introduction of mafsadah (harmfulness) against human. Hence, further research is needed to propose ways in dealing with antibiotic resistance issues at the national level to prevent and control the spread of antibiotic resistance in the country.
\end{abstract}

Keywords: Antibiotic, Resistance, Halal, Animal Production, Shariah Perspective

\section{Introduction}

Antibiotic referred to a substance produced by a microorganism or any other product which is produced wholly or partially by chemical synthesis, wherein low concentration inhibits the growth of or kills micro-organisms and is utilized for growth stimulation and prevention of diseases (Feed Act, 2009). In animal production, antibiotics have been used for therapeutic purposes against infectious disease, prophylactic use for prevention of infectious 
animal diseases, and also sub-therapeutic use as feed additives for animal production and improvement of feed utilization (Landers et al., 2012). In sub-therapeutic use, the drug is administered at dosages insufficient to produce a therapeutic effect but provides other benefits for animal growth. In fact, many countries are using antibiotics as an antimicrobial growth promoter (AGPs) which has arisen concern on increasing resistance to antibiotics worldwide, due to overutilization of this compound in animal farming (Vieco-Saiz et al., 2019).

The use of antibiotics in animal production has led to serious public health problems worldwide. This is especially so in the case where the utilization of classes of antibiotics for animal growth promoters is similar to the one that is used for human medication. With the increasing resistance found in bacterial strains from food animals, it is apparent that the available antibiotics used to treat infections in humans are becoming less efficient. Based on the increasing reports and issues on antibiotic utilization in animal production, it is evident that this matter needs serious consideration worldwide. This study was therefore conducted to analyze the Shariah position on utilization of antibiotics in animal production, besides identifying related issues on antibiotic utilization in Malaysia.

\section{Literature Review}

Antibiotics have long been used in animal farming, which was started with the utilization of synthetic sulphonamides in 1935 in Germany (Kirchhelle, 2018). Bayer, the German pharmaceutical manufacturer has successfully marketed Prontosil (sulfochrysiodine), the firstly known effective drug against Gram-positive bacterial infections for human and agricultural use (Kirchhelle, 2018). In addition, gramicidin was started being used to treat the mass outbreak of mastitis (Udder infection in cows) at the New York World Exhibition (Bud, 2007). Besides, penicillin was also tested against mastitis during the second world war, due to wartime milk's importance as leading food to humans (Cozzoli, 2014).

In the last ten years, the use of antibiotics in animal production was estimated at 63,151 tons and is expected to increase by $67 \%$ by the year 2030 (105,569 tons) (Van Boeckel et al., 2015). The dependency on the use of antibiotics in animal production is highly associated with the economic impact resulting from its application. Antibiotic use is proven to improve feed efficiency, by a reduction in the cost of animal maintenance, besides protecting the animal at critical growth stages. Furthermore, mortality reduction is also reported from the use of growth-promoting antibiotics.

Nevertheless, some researchers believe that the use of growth-promoting antibiotics (GPAs) in animal production could be associated with economic losses to the producer. Economic analysis of antibiotic removal from commercial broiler production by (Graham, Boland, \& Silbergeld, 2007) showed a lost value of $\$ 0.0093$ per chicken (about $0.45 \%$ of total cost) in the use of GPA. The profit gained through the utilization of GPAs was inadequate to outweigh the cost of the antibiotic. Moreover, the use of GPAs is connected to the increase in antibiotic resistance infection in animals and humans. Based on the findings, it was suggested that the use of growth-promoting antibiotics in animal production should be reconsidered (Graham et al., 2007).

Many studies had demonstrated the association between antibiotic use in animal nutrition and the prevalence of antibiotic-resistant bacteria. Antibiotic-resistant bacteria had been detected from various sources such as processed and raw meat products and the environment surrounding livestock farming operations. Landers et al. (2012) had reviewed the research that suggests a potential relationship between antibiotic use in food animals and antibiotic resistance in humans. The study demonstrated that the utilization of antibiotics in 
animal production has led to the occurrences of antibiotic resistance in food animals, the environment surrounding livestock farming operations, food products on the market, and human. It was also astonishing to find infections from resistant bacteria that identical to those recovered from cattle and poultry (Landers et al., 2012).

A study conducted by Mansouri-najand et al., (2012) had determined the presence of Campylobacter spp. in live chickens sold at the wet markets in Selangor, Malaysia, and the multidrug resistance (MDR) profiles of the isolates. The findings of this study showed a high prevalence

Campylobacter spp. with more than $75 \%$ of the chicken samples were found positive. The Campylobacter spp. were also found to be resistant to some antibiotics such as cephalothin (95.5\%), tetracycline (80.8\%), erythromycin (51.4\%), enrofloxacin (42.4\%) and gentamicin (24.4\%), while multidrug resistance (resistant to four or more antibiotics) was detected in $35.3 \%$ of the isolates. The writers urged that careful use of antibiotics should be applied in the poultry production, with comprehensive monitoring to reduce the spread of the multidrug resistance Campylobacter.

\section{Result and Discussion}

\section{Antibiotic Resistance Issues in Malaysia}

In Malaysia, the detection of antibiotic-resistant bacteria strains was repeatedly reported from food products. For example, Salmonella strains, resistant to tetracycline, polymixin B, erythromycin, chloramphenicol, penicillin G, and trimethoprim were isolated from local chicken tested by DVS, while imported chicken tested were positive for Salmonella (Hamid, 2012).

Besides, Campylobacter bacteria that could cause diarrhoea was detected from cattle, beef meat (Premarathne et al., 2017), and live chickens sold at the wet market in Selangor (Mansouri-najand et al., 2012). In fact, from all 340 samples collected, the prevalence of Campylobacter was $17.4 \%$, consisting of $33 \%$ in cattle fecal samples, $14.2 \%$ in raw beef from the wet market, and $7.5 \%$ in raw beef from the hypermarket (Premarathne et al., 2017). Besides, based on the test results by Mansouri-najand et al. (2012), the collected Campylobacter strains are resistant to few antibiotics such as cephalothin, tetracycline, erythromycin, enrofloxacin, and gentamicin, and more than thirty percent of the tested bacteria demonstrate multidrug resistance (Mansouri-najand et al., 2012). Also, analysis done on bacteria isolated from frozen burger patties indicated the presence of multidrug resistance Listeria monocytogenes which are mostly resistant to tetracycline, but susceptible to imipenem and gentamicin (Wong et al., 2012).

Furthermore, a study conducted to examine the level of veterinary antibiotics pollution in broiler manure showed that all samples were contaminated either with progesterone, or antibiotics (Ho et al., 2014). Antibiotics detected include doxycycline, enrofloxacin, flumequine, norfloxacin, trimethoprim, and tylosin, in high concentrations. Based on the concentration level of the antibiotic in manure samples, it is evident that these antibiotics and hormones had been administered at high levels to the broiler. This situation poses a risk to agricultural activity due to the possibility of contaminating the agricultural soil via fertilization with animal manure (Ho et al., 2014). Besides, the use of poultry by-products and manure as aquaculture feed could also lead to the contamination of aquaculture fish by veterinary antibiotics. 
Similarly, antibiotic-resistant bacteria have also been isolated from many other food products in Malaysia. Research by Budiati et al (2013) had isolated antibiotic-resistant Salmonella from catfish (Clarias gariepinus), and tilapia (Tilapia mossambica) obtained from wet markets and ponds in Malaysia. These cultivated fish were fed commercial fish feed, chicken offals, and spoiled eggs. Kathleen et al. (2016) in their examination of antibiotic resistance in bacteria from aquaculture products and aquaculture's surrounding environment in Sarawak had discovered multiple antibiotic-resistant strains (MAR) with MAR index of 0 to 0.63. Resistance to streptomycin was observed from $85 \%$ of all the bacterial isolates.

In the latest study by Haulisah et al. (2021), situational analysis of antimicrobial resistance from clinical isolates of diseased food animals has identified 701 isolates of antibiotic-resistant bacteria. The clinical specimens were collected from 241 cases of diseased livestock involving ruminants (cattle, sheep, and goat) and non-ruminants (chicken and pigs). Findings showed that antibiotic sensitivity testing (AST) conducted revealed that $E$. coli resistance was highest for penicillin, streptomycin, and neomycin (77-93\%). Besides, $S$. aureus was highly resistant to neomycin, followed by streptomycin and ampicillin (68-82\%). The results also demonstrated multi-drug resistance of $67 \%$ of $E$. coli isolates, with $2.6 \%$ were susceptible to every tested antibiotic. Similar findings were demonstrated by aureus isolates where $65.6 \%$ were MDR and only $5.5 \%$ were susceptible to all tested antibiotics.

Likewise, in aquaculture production, the use of poultry by-products such as chicken offal and spoiled eggs as feed in aquaculture farming may lead to the dissemination of antibiotic genes to the aquaculture fish and the surrounding environment. This is evident based on a study by (Budiati et al., 2013) where Salmonella was detected in catfish and tilapia samples from the wet market and ponds. The positive samples were obtained from the pond fed with chicken offal, spoiled eggs, and commercial feed. There was a significant difference $(P<0.05)$ in the occurrence of Salmonella fed with spoiled eggs $(6 / 6)$ compared to those fed with formulated feed (1/6). Most Salmonella serovars isolated from catfish and tilapia in this study were resistant to chloramphenicol, rifampicin, and tetracycline. It is obvious from the study that the use of feed made from animal by-products such as the chicken offal and spoiled eggs may increase the probability of bacterial transfer into the aquaculture surrounding, which may eventually transfer the Salmonella spp. to the fish, and finally reach humans through fish consumption.

Certain antibiotics such as chloramphenicol, nitrofurans, teicoplanin, vancomycin, carbadox, and olaquindox are prohibited to be used in feed and feed additives for foodproducing animals in Malaysia [Peraturan-peraturan Makanan Haiwan (Antibiotik, hormon dan bahan kimia lain terlarang) 2012, 2012]. Nevertheless, traces of nitrofurans and chloramphenicol has been found in shrimp and prawns exported to the United States of America (Yunus, 2016), and has led to the detention of its shipments from Malaysia. According to the report, out of 138 shrimp and prawn samples tested between October 2014 and September 2015, 45 samples were positive to contain residues of chloramphenicol or nitrofurans. Based on the reported issues, it is therefore important that appropriate laws and regulations on the use of antibiotics in animal nutrition should be considered properly by the authorities.

\section{Utilization of Antibiotics in Animal Production: Shariah Perspective}

The utilization of antibiotics in animal production is a common practice globally. This chemical compound is added to the feed and drinking water of food-producing animals to promote 
growth and help to gain weight faster while reducing the amount of feed utilized to gain optimum weight. Antibiotics have been continually and widely used due to their benefit in animal rearing, which contributes significantly to the development of meat security in Malaysia.

The utilization of the antibiotic in animal production could be viewed from its usage for medicinal purposes and as growth promoters. It is essential to use antibiotics in the agricultural sector to treat diseases related to bacterial infections in animals. The usage is crucially important in preventing the spread of disease from food animals to humans. Nevertheless, due to the possibility of adulteration among feed manufacturers and farmers, the utilization of antibiotics should be carefully monitored to prevent unnecessary and overusage. Indeed, this approach is closely associated with the Shariah principle known as sadd al-dharai' (blocking the means) where certain permissible conducts are prevented if it is known to lead to a certain harmful end. Referring to the case of antibiotic utilization in animal production, the objective of controlling the use of antibiotics, under those circumstances, is to prevent harm from happening to the animals and humans by only permitting the usage of the antibiotics at the permitted level.

Hence, when referring to the context of antibiotics utilization as medication in treating bacterial infections in animals, the appropriate maxim that could be applied is irtikab akhaf al-dararayn (committing the lesser of two evils). This principle should be carefully observed so that the interests of both the animals and humans as the end-users are considered. This indeed in conformity with the hadith "la darar wa la dirar" (harm shall neither be inflicted nor reciprocated) which means that although there is a need to use antibiotics in animal production for the prevention and treating of diseases, this practice shall be carried out according to appropriate preventive measure in terms of its dosage, administration methods and withdrawal periods which should be based on the prescription. This is to avoid the possibility of consuming animal-based food products that still have remaining traces of antibiotics which may pose adverse effects to the health of the consumers.

This problem could happen if excessive antibiotics residues are found in meat-based products due to inappropriate use. It is therefore important for aquaculture farmers and livestock breeders to make sure that the specific withdrawal period as specified in the product labelling is respected. Negligence of the withdrawal period may lead to the possibility of the animal being consumed within the withdrawal period. In fact, this treated animal or its products are unfit for human consumption during the withdrawal period because consuming this animal may affect human health. Animals treated with drugs or antibiotics will have residues of the compounds which will end up in the meat, milk, and eggs, and that drug and their by-products level will only decline after a few days. The time that passes between the last administration of an antibiotic or a drug and the moment when the drug residues level falls below the maximum allowable limit (Maximum Residue Limit - MRL) in the meat, milk, or eggs is called the withdrawal period. The withdrawal period should be respected to eliminate the possibility of allergy, cancer, antibiotic resistance, and other health effects to humans, through the consumption of animal-based food products.

On account of this, proper monitoring on the utilization of permitted antibiotics and their dosage for animals is compulsory to avoid the occurrence of health hazards to human beings. This is in line with the principle of halal and haram that mentioned, "the prohibition of things is due to their impurity and harmfulness" (Al-Qardawi, 2013). The benefits of antibiotics usage should outweigh the risks that could be introduced by its application. Yet, if the risk introduced by its utilization is greater, then the utilization should be prevented with 
proper control. This is because the practice will eventually be affecting the halal food supply chain where the last chain is the consumer. Having said this, specific regulations under the Food Regulation 1985, regulation 40, and its sub regulations have clearly emphasized the permitted drugs and the maximum permitted proportion of drug residues in food. Therefore, continuous monitoring and enforcement should be carried out by the authorities to ensure the minimum effect of its utilization on animals and human health.

Besides being used as medicine, antibiotics are also commonly be utilized as growth promoters in livestock farming. Farmers are reportedly using antibiotics in the farming industry to reduce feed costs (Muhammad Amin, 2019) where it was reported that $70 \%$ of the operational cost was allocated to the animal feed (Yunus et al., 2010). This resulted in increased appetite of the animals to consume more food and their growth will increase as well. Nevertheless, the utilization of antibiotics as a growth promoter has been linked to the development of antimicrobial resistance, which may cause risk not only to human health but also to the surrounding environment (Dibner \& Richards, 2005). Thus, careful monitoring of the usage of antibiotics among the farmers is very important to avoid unnecessary adverse effects on the consumers and the surrounding environment.

Eventually, this matter would directly affect halal food security as well because halal meat-based food products do not only concern with the source of animal's origin per se, but also including the tayyibban aspect. Owing to this, the process of feeding the animals is crucial to fulfil the requirement of the tayyibban aspect. From the perspective of Maqasid al-Shariah, the utilization of antibiotics for medicinal purposes is needed as there is an element of dharurah, where it is to protect the animal with proper treatment in ensuring the meat is sufficient and safe to the people. Likewise, its utilization as a growth promoter only falls within tahsiniyyat whereby according to Muhammad Amin (2019), the probiotic is among the best halal alternative in replacing the usage of antibiotics because it could provide more nutrients to the animal body. In the end, this halal alternative could increase animal growth as the wellmannered and the halalan tayyiban requirements are fulfilled.

\section{Conclusion}

Antibiotic resistance and veterinary drugs residues are among the issues associated with inefficiencies in the management and use of veterinary drugs. Based on the findings of this study, it is apparent that there are many issues related to antibiotic resistance occurrence in Malaysia which include detection of multiple antibiotic resistant bacteria in food products such as from cattle, live chickens, raw poultry and beef meats, frozen burger patties, aquaculture-fish and also from diseased food animals. These bacteria isolates are highly resistant to multiple antibiotics including those that are commonly used for treatment against human infection. The study also concluded that from the Islamic perspective, utilisation of antibiotic in animal production are permissible for the treatment of disease related to bacterial infection, with appropriate monitoring to prevent unnecessary and over-usage. Hence, utilization of antibiotics as growth promoter should be reconsidered since it has been connected with the increase of antimicrobial resistance which could compromised the animal and human health.

Based on the current situation and issues related to antibiotic utilization and Shariah position explained in this study, it is suggested that, for medication and treatment purposes, utilization of antibiotics and veterinary drugs in halal animal production shall only be used with approval from the competent authorities or certified Veterinarian, and utilization of banned substances shall be highly prohibited. This is so because only those licensed 
veterinarian could legally use and dispense a prescription for veterinary drugs within the course of their professional practices.

\section{References}

Al-Qardawi, Y. (2013). Halal dan haram menurut perspektif Islam (A. E. Al-Mubarak, Ed.; Third). Perniagaan Jahabersa.

Budiati, T., Rusul, G., Wan Abdullah, W. N., Arip, M. Y., Ahmad, R., \& Thong, K. L. (2013). Prevalence, Antibiotic Resistance and Plasmid Profiling of Salmonella in Catfish (Clarias gariepinus) and Tilapia (Tilapia mossambica) obtained from Wet Markets and Ponds in Malaysia. Aquaculture, 372-375, 127-132.

https://doi.org/10.1016/j.aquaculture.2012.11.003

Cozzoli, D. (2014). Penicillin and the european response to post-war American hegemony: The case of leo-penicillin. History and Technology, 30(1).

https://doi.org/10.1080/07341512.2014.902232

Dibner, J. J., \& Richards, J. D. (2005). Antibiotic growth promoters in agriculture: History and mode of action. Poultry Science, 84(4), 634-643. https://doi.org/10.1093/ps/84.4.634

Ronquillo, G. M., \& Hernandez, A. J. C. (2017). Antibiotic and Synthetic Growth Promoters in Animal Diets: Review of Impact and Analytical Methods. Food Control, 72, 255-267. https://doi.org/10.1016/j.foodcont.2016.03.001

Graham, J. P., Boland, J. J., \& Silbergeld, E. (2007). Growth Promoting Antibiotics in Food Animal Production: an Economic Analysis. Public Health Reports, 122(February), 79-87. https://doi.org/10.1177/003335490712200111

Hamid, A. N. (2012). Coutry Report: Malaysia. Proceedings of the International Workshop on the Use of Antimicrobials in Livestock Production and Antimicrobials Resistance in the Asia Pacific Region, 1-8.

Haulisah, N. A., Hassan, L., Bejo, S. K., Jajere, S. M., \& Ahmad, N. I. (2021). High Levels of Antibiotic Resistance in Isolates From Diseased Livestock. Frontiers in Veterinary Science, 8. https://doi.org/10.3389/fvets.2021.652351

Ho, Y. bin, Zakaria, M. P., Abdul Latif, P., \& Saari, N. (2014). Occurrence of Veterinary Antibiotics and Progesterone in Broiler Manure and Agricultural soil in Malaysia. Science of the Total Environment, 488-489(1), 261-267. https://doi.org/10.1016/j.scitotenv.2014.04.109

Kathleen, M. M., Samuel, L., Felecia, C., Reagan, E. L., Kasing, A., Lesley, M., \& Toh, S. C. (2016). Antibiotic Resistance of Diverse Bacteria from Aquaculture in Borneo. International Journal of Microbiology, 2016. https://doi.org/10.1155/2016/2164761

Kirchhelle, C. (2018). Pharming animals: a global history of antibiotics in food production (1935-2017). Palgrave Communications, 4(1). https://doi.org/10.1057/s41599-0180152-2

Landers, T. F., Cohen, B., Wittum, T. E., \& Larson, E. L. (2012). A Review of Antibiotic Use in Food Animals: Perspective, Policy, and Potential. Public Health Reports (Washington, D.C. : 1974), 127(1), 4-22.

http://www.ncbi.nlm.nih.gov/pubmed/22298919\%5Cnhttp://www.pubmedcentral.ni h.gov/articlerender.fcgi?artid=PMC3234384

Mansouri-najand, L., Saleha, A. A., \& Wai, S. S. (2012). Prevalence of Multidrug Resistance Campylobacter jejuni and Campylobacter coli in Chickens Slaughtered in Selected Markets, Malaysia. Tropical Biomedicine, 29(2), 231-238. 
Yunus, M. A., Chik, W. M. Y., \& Mohamad, M. (2010). The Concept of Halalan Tayyiba and Its Application in Products Marketing: A Case Study at Sabasun HyperRuncit Kuala Terengganu, Malaysia. 1(3), 239-248.

Amin, M. J. (2019). Konsep Halalan Toyyiban dalam sumber makanan ternakan. Berita Harian Online.

Premarathne, J. M. K. J. K., Anuar, A. S., Thung, T. Y., Satharasinghe, D. A., Jambari, N. N., Abdul-Mutalib, N. A., Yew Huat, J. T., Basri, D. F., Rukayadi, Y., Nakaguchi, Y., Nishibuchi, M., \& Radu, S. (2017). Prevalence and Antibiotic Resistance against Tetracycline in Campylobacter jejuni and C. coli in Cattle and Beef Meat from Selangor, Malaysia. Frontiers in Microbiology, 8(DEC). https://doi.org/10.3389/fmicb.2017.02254

Van Boeckel, T. P., Brower, C., Gilbert, M., Grenfell, B. T., Levin, S. A., Robinson, T. P., Teillant, A., \& Laxminarayan, R. (2015). Global Trends in Antimicrobial Use in Food Animals. Proceedings of the National Academy of Sciences of the United States of America, 16, 1-6. https://doi.org/10.1073/pnas.1503141112

Vieco-Saiz, N., Belguesmia, Y., Raspoet, R., Auclair, E., Gancel, F., Kempf, I., \& Drider, D. (2019). Benefits and inputs from lactic acid bacteria and their bacteriocins as alternatives to antibiotic growth promoters during food-animal production. In Frontiers in Microbiology (Vol. 10). https://doi.org/10.3389/fmicb.2019.00057

Wainwright, M. (2007). Penicillin: Triumph and Tragedy. Social History of Medicine, 20(3). https://doi.org/10.1093/shm/hkm084

Yunus, A. (2016). US FDA May Detain Imports of Malaysian Prawns, Shrimp. The Star Online. http://www.thestar.com.my/news/nation/2016/04/20/us-fda-malaysian-prawns/ 